\title{
Third Parties' Legal Protection Over Agreed Authorized Capital Amount By Founders In Limited Liability Companies
}

\author{
Xavier Nugraha \\ Airlangga University, Indonesia \\ xavier.nugraha-2015@fh.unair.ac.id
}

Krisna Murti

Airlangga University, Indonesia

krisnagaga@gmail.com

Saraswati Putri

Airlangga University, Indonesia

saraswatiputri942@gmail.com

\section{ABSTRACT}

On July 14, 2016, the Government enacted Government Regulation Number 29 of 2016 (GR 29/16) regarding Amendments in Authorized Capital of a Limited Liability Company (LLC). Article 1 paragraph (3) of the regulation showed that the amount of authorized capital was submitted to the agreement of the LLC founders. This regulation was issued in order to increase Indonesia's 'ease of doing business' rank, especially in 'starting business.' This article aims to examine the legal protection for the third party over the amount of authorized capital based on the agreement of the LLC founders using the study of dogmatic law. Regulations referenced are Law Number 40 of 2007 regarding Limited Liability Companies and Government Regulation Number 29 of 2016 regarding Amendments in Authorized Capital of LLC. Based on the results of this study, it was found that the determination of authorized capital based on the agreement of LLC founders has neglected the protection of the third parties. This manifested particularly in protecting minority investors and resolving insolvency. Through the enactment of authorized capital based on the agreement of the founders, the mechanism of preventive and repressive legal protection to the third parties are assumed to be eliminated

KEYWORDS: The Authorized Capital, Limited Liability Company, Agreement, Legal Protection.

Copyright $\odot 2019$ by Author(s)

This work is licensed under a Creative Commons Attribution-ShareAlike 4.0 International License. All writings published in this journal are personal views of the authors and do not represent the views of this journal and the author's affiliated institutions.

\section{HOW TO CITE:}

Nugraha, Xavier \& Krisna Murti \& Saraswati Putri. "Third Parties' Legal Protection Over Agreed Authorized Capital Amount By Founders In Limited Liability Companies” (2019) 6:2 Lentera Hukum 173-188.

Submitted: February 03, 2019 Revised: March 07, 2019 Accepted: June 02, 2019 


\section{INTRODUCTION}

Today's business world is experiencing rapid growth. To develop a business, the first step is to acquire a business entity. A business entity consists of two parts: a non-legal entity and a legal entity. Non-legal business entities comprise of trade business, firm, maatschap, and military company while legal business entities can be found as limited liability companies (LLC), foundations, cooperatives, and other legal entities. ${ }^{2}$ Among the varied business entities, the most widely used entity in Indonesia is "Perseroan Terbatas (PT)" or limited liability companies (LLC). LLC's are preferred because there is a clear separation between personal wealts and assets of the company. This schematic is different from other non-legal business entities because the LLC founders' responsibilities is not limited to the wealth invested in the business entity but can also include the personal wealth of the founders. The risk would be greater for non-legal entities because accountability can bleed into the founder's private property. ${ }^{3}$ For these reasons, an LLC is considered a "persona standi in judicio" because its entity is independent and separated from an individual interest. ${ }^{4}$ Additionaly, LLC is the only business entity with a 'pure' commercial orientation, making it the most appropriate form of business to to form a profit oriented business. ${ }^{5}$ The following are basic characteristics and privileges of an LLC that could not be found in other business entities: ${ }^{6}$

1. It is a legal entity

2. It is a collection of capital/shares

3. It has assets that are separated from the wealth of the parapers

4. Its shareholders have limited responsibilities

5. There is a separation of functions between shareholders and management or direction

6. It has a commissioner who functions as a supervisor

7. Its highest power is in the General Meeting of Shareholders (GMS).

Arrangements related to LLC as a legal entity can be found in Article 1 number 1 of Law Number 40 of 2007 concerning Limited Liability Companies ("Company Law”), which states:

"Limited Liability Company, hereinafter referred to as the Company, is a legal entity

which is a set of capital, established under an agreement, in order to conduct business

1 Yoahana, 'Tanggung Jawab Hukum Atas Bentuk Usaha Badan Hukum Dan Bentuk Usaha Non Badan Hukum' 8 number 1 of 2015 Jurnal Mecatoria at 47.

2 Hukumonline.com, "Jenis Badan Usaha dan Karakteristiknya" 20 March 2012 https://www.hukumonline.com/klinik/detail/lt4f51947253585/jenis-jenis-badan-usaha-dankarakteristiknya.

3 Agus Riyanto. "Mengapa Harus Memilih Perseroan Terbatas?", (2012), online: < http://businesslaw.binus.ac.id/2017/10/31/mengapa-harus-memilih-perseroan-terbatas/1〉.

4 Purbandari, 'Tanggung Jawab Hukum Perseroan Terbatas (Pt) Yang Dinyatakan Pailit', 1 Number 1 of 2014 Jurnal Widya Yustisia at 31.

5 Gledisia Deyaperdana, "Pelaksanaan Tanggung Jawab Sosial Perusahaan PT Indosat Tbk (Studi Pada Kantor Perwakilan Kotabumi)", Thesis, Fakultasof LawUniversitas Lampung, (2010) at 19.

6 Irma Devita, "Pendirian Perseroan Terbatas", (2007), online: 〈http://www.legal4ukm.com/pendirianperseroan-terbatas-pt/,>. 
activities with the Company's authorized capital which are all divided into shares, and fulfill the requirements stipulated in this Law and the implementing regulations."

From the above definition, an LLC's most important component is capital.. This capital-centered system distinguishes an LLC from civil partnership (maatschap) regulated in Article 1618 of Burgerlijk Wetboek (BW) - as well as firms and CVsregulated in Article 16 to Article 35 of the Commercial Law. These three forms are called associate personnel (personen associate) ${ }^{7}$

There are three (3) types of capital in an LLC,: authorized capital (maatschappelijkcapitaal), issued capital (geplaatscapita al), and paid-up capital (gestortcapitaal). ${ }^{8}$ Authorized capital is the whole nominal values of the LLC shares referred in the Articles of Association and is not considered as real capital. This implies that an LLC's wealth could not be calculated based on the amount of its authorized capital but rather the total number of shares issued by the LLC. The Articles of Association determines how many shares can be used as authorized capital. The amount specified in the Articles of Association is a "pure nominal value." 9 As a result, this authorized capital can be used to categorize the class of a certain LLC. According to Article 32 paragraph (1) of Company Law, the minimum amount of the authorized capital is at least Rp50,000,000,- (fifty million rupiah)..

Issued capital is a type of capital that is agreed upon by the founders or shareholders for repayment. These shares have been handed over to the company's management team for ownership. ${ }^{10}$ If a shareholder is capable of investing 30\% of the authorized capital then the amount of the issued capital is $30 \%$. Similar to authorized capital, issued capital is not a real capital because the capital has not been fully deposited. ${ }^{11}$ Issued capital only demonstrates the ability of the shareholders to invest their capital into the particular company. By the Article 33 paragraph (1) of the Company Law, the minimum amount of the Issued Capital is 25\% of the authorized capital or Rp12,500,000,- (twelve million five hundred thousand rupiah).

Paid-up capital is a capital categorized as a real capital because it has been deposited into the company. In this case, the shareholders have to store their capital into the LLC. ${ }^{12}$ The minimum amount of paid-up capital, according to the Company Law, is the same amount of the issued capital which is at least 25\% (twenty five percent) of the authorized capital. This amountmust be issued and paid in full. The

\footnotetext{
Bahmid, 'Perubahan Persekutuan Perdata Menjadi Badan Hukum Perseroan Terbatas', 2 No. 4 of 2018 Jurnal Pionir LPPM Universitas Asahan at 5.

8 Shanti Rachmadsyah, "Perbedaan Modal Dasar, Modal Ditempatkan, dan Modal Disetor PT", (2017), online: < https://www.hukumonline.com/klinik/detail/lt4cd0bd0284a7l/perbedaan-modal-dasar-modal-ditempatkan--dan-modal-disetor-pt>.

9 Yahya Harahap, Hukum Perseroan Terbatas, (Jakarta: Sinar Grafika, 2016) at 233.

$10 \quad$ Ibid at 236.

11 Legalakses, "Modal Perseroan Terbatas", (2014), online: < http://www.legalakses.com/modalperseroan-terbatas/>.

12 Yahya Harahap supra note 9 at 236.
} 
amount has been stated in Article 33 paragraph (1) of the Company Law. ${ }^{13}$

On March 21, 2016, the Government issued Government Regulation Number 7 of 2016 concerning Amendments to Limited Liability Companies (PP No. 7 Tahun 2016). Based on is Article (1), there was a change in the authorized capital setting which was initially determined to be at least Rp50,000,000,- (fifty million rupiah). The change focuses on a new criteria related to an LLC's founder's net assets. These criteria come from the qualitie of Micro, Small and Medium Enterprises (MSMEs). The issuance of this regulation is part of the Indonesian Economic Programme called "Paket Kebijakan Ekonomi XII," in which the Government intends to provide the ease of doing business for small and medium enterprises. ${ }^{14}$

On July 14, 2016, shortly after the issuance of the regulation, the Government reissued a new policy regarding changes in the authorized capital setting from establishing an LLC. The policy replaced the previous policy, Government Regulation No. 7 of 2016, and is included in Government Regulation Number 29 of 2016 (PP No. 29 Tahun 2016) regarding Amendments in Authorized Capital of a Limited Liability Company. The new policy stated that an LLC's authorized capital as referred to in Government Regulation No. 7 of 2016 to be at least Rp50,000,000,- (fifty million rupiah), mustbe submitted to the agreement of the founders of the LLC if the founders had net assets pursuant to the criteria of Micro, Small and Medium Enterprises (MSMEs). This is in accordance with Government Regulation Number 29 of 2016. ${ }^{15}$

The Investment Coordinating Board (BKPM)'s Deputy for Investment Implementation Control, Azhar Lubis, states this policy was taken to raise Indonesia's level of "the Ease of Doing Business', especially for starting business. ${ }^{16}$ Based on the results of the Ease of Doing Business (EODB) 2017 Report by the World Bank conducted in Indonesia, Indonesia was ranked 91 st out of 190 countries in the world. ${ }^{17}$ In the indicator of starting a business, Indonesia is considered as one of the countries with the most complex and high-cost procedures. Indonesia has the lengthiest processes and the longest completion time among the main ASEAN member countries. ${ }^{18}$ This report motivated the Government to re-examine the minimum authorized capital required to establish an LLC. Furthermore, the explanation of the Government Regulation Number 29 of 2016 concerning general provisions suggests that the Indonesian Government's is

13 Nabila Jofita Kumalasari, "Perlindungan Hukum Pihak Ketiga Terhadap Modal Perseroan Terbatas Berdasarkan Peraturan Pemerintah Nomor 29 Tahun 2016 Tentang Perubahan Modal Dasar Perseroan Terbatas", Thesis, Faculty of Law Airlangga University, (2018) at 5.

14 Siti Yuniarti, "Perubahan Modal Dasar Perseroan Terbatas", (2016), online: 〈http://businesslaw.binus.ac.id/2016/04/29/perubahan-modal-dasar-perseroan-terbatas/>.

15 Joshua Agustha, "Inkonsistensi Pengaturan Modal Dasar Dalam Pendirian Perseroan Terbatas Terhadap Tujuan Kepastian Hukum", Thesis, Faculty of LawAtmajaya University Yogyakarta, (2017) at 5 .

16 Nabila Jofita Kumalasari Op.cit page 7 in Elisa Valenta Sari, "Pemerintah akan Hapus Syarat Modal Dasar Pembentukan PT", (2016), online: 〈https://www.cnnindonesia.com/ekonomi/2016030318312592-115198/pemerintah-akan-hapus-syarat-modal-dasar-pembentukan-pt〉.

17 Doing Business, Rankings, Online: < http://www.doingbusiness.org/en/rankings〉.

18 Kemenkumham, "Naskah Akademik Rancangan Undang-Undang Perseroan Terbatas," (2016), online: 〈https://www.bphn.go.id/data/documents/na_ruu_pt.pdf $>$ at 3. 
attempting to have more flexile laws so that businesses can more easily be founded.

However, the enactment of Government Regulation Number 29 of 2016 has resulted in a lack of certainty regarding the minimum amount of LLC's authorized capital. This article will suggest how such implementation will have an impact on the sustainability of the LLC itself because it allows low capital enterprises to skip potentially important steps like accruing enough capital. In particular, third party investors of low capital LLC's are in unstable circumstances with little security. With this focus in mind, the research explores the necessity and formulation of legal protection for third parties over the amount of authorized capital stipulated in Government Regulation Number 29 of 2016.

\section{AUTHORIZED CAPITAL AS A FORM OF LEGAL PROTECTION FOR THIRD PARTIES}

In economics, capital is defined as the embodiment of a group of objects such as goods, money, and results used by a business entity to gain profits. Capital is one component of a company's assets calculated together with the debt that the company has. To conduct business activities, an LLC must have sufficient funds (later to be called as a capital based on the Company Law). In the explanation of Article 41 paragraph (1) of the Company Law, company capital is authorized capital, issued capital, and paid-up capital. $^{19}$

"The beginning of wisdom is the definition of terms." ${ }^{20}$ Contrary to this quote from Socrates's, there has not been any single law that provides a clear definition of authorized capital despite being referenced numerous times in other laws. In Company Law, there is only a concept of authorized capital in Article 31 paragraph (1) which states that the company's authorized capital consists of all nominal value of stocks. Rochmat Soemitro, R. T. Sutantya R. Hadhikusuma, and Sumantoro define authorized capital as the amount of capital mentioned in the deed of establishment of LLC, which is the maximum amount of authorized capital of the company. ${ }^{21}$ The amount of authorized capital is the nominal amount of all stocks which will be issued according to the Articles of Association. ${ }^{22}$ This issued of shares becomes one of the means for an LLC to obtain money. Such wealth is used by an LLC to launch the business activities specified in the Articles of Association. ${ }^{23}$ The authorized capital amount must be referred to and included in the Articles of Association as the amount of capital that

19 Azizah, Hukum Perseroan Terbatas, (Intimedia: Malang, 2015) at 68.

20 "Socrates dan Definisi Terorisme", (2018), retrieved from online: < https://pinterpolitik.com/socratesdan-definisi-terorisme/s.

21 Yohana Feryna, 'Makna Kesepakatan Para Pihak Terhadap Perubahan Modal Dasar Perseroan Terbatas' 7 Nomor 2 Tahun 2016 Jurnal Cakrawala Hukum, page 258 in Rochmat Soemitro, R.T. Sutantya R. Hadhikusuma, and Sumantoro, Pengertian Pokok Hukum Perusahaan, (Jakarta: Rajawali, 1992) at 39.

22 Man S. Sastrawidjajaand Rai Mantili, Perseroan Terbatas Menurut Tiga Undang-undang Jilid 1, (Bandung: Alumni, 2008) at 14.

23 Yahya Harahap supra note 9 at 233. 
must be "divided" in shares with a fixed nominal value that can be enlarged by issuing new shares. ${ }^{24}$

The amount mentioned in the Articles of Association that shows the nominal amount of all shares is often assumed to represent the financial strength of a particular LLC. This assumption is not necessarily accurate because, in fact, the amount of paidup capital given by the shareholders more accruately represents a company's strength. From the authorized capital, each founders of the company takes part in the shares as issued capital. ${ }^{25}$ This amount shows the real financial strength of a company.

Historically, the regulation of LLC's authorized capital in Indonesia first ocurred in Wetboek Van Koophandle or Indonesian Commercial Code (KUHD). Nevertheless, the regulation did not include a specified amount for authorized capital.The existing arrangements related only to the company's capital ownership where the first founders together represented at least one-fifth of the company's capital, ${ }^{26}$ and that the amount of capital required to be paid is ten percent $(10 \%)$ of the authorized capital. ${ }^{27}$

In its development, the business practices in the form of LLC were accelerated the existing regulations regarding an LLC were considered unable to meet the needs of business actors. Subsequently, Law Number 1 of 1995 concerning Limited Liability Companies became the first regulation to specifically regulate an LLC. The reason for this Company Law was to ensure that economic activity can continue to be sustainable and harmonious as well as to establish protections for the creditors. ${ }^{28}$ One of the ways to develop a protections mechanism was through establishing minimum capital requirements.

The minimum amount of the authorized capital for establishing an LLC was introduced in 1978 as a result of the second EEC Directive concerning company law in 1976. This requirement became crucial for public companies which were still limited by shares. However, the Dutch legislators voluntarily also introduced minimum authorized capital amount for NV. ${ }^{29}$ That was done for the company's creditors to get legal protection in the form of a minimum authorized capital.

The minimum amount of authorized capital used for the establishment of this LLC can be used as collateral by the LLC against third parties if the LLC has a certain amount of debt. In such a way, if the LLC wants to apply for credit, then a credit agreement must be made. As the credit agreement is known as an obligatory agreement, the creditor will automatically get a legal guarantee from the debtor since the issuance of an agreement will make an indvidual's property a legal subject bound to the opposite party.

Ibid at 234.

25 Gatot Supramono, Transaksi Bisnis Saham e penyelesaian Sengketa Melalui Pengadilan, (Jakarta: Pranamedia Group, 2014) at 15.

26 Article 50 Indonesian Commercial Code.

27 Article 51 Indonesian Commercial Code.

28 General Overview on Law Number 1 of 1995 regarding Limited Liability Company.

29 Lars van Vliet, 'The Netherlands - New Developments in Dutch Company Law: The "Flexible" Close Corporation', 7 No.1 2014,J. Civ. L. at 276. 
The minimum authorized capital amount to establish an LLC is in accordance with the principle of creditorium parity which is one of the main principles of a debt settlement. This is in line with Vollmar's argument, stated in the following way: "een der belangrijkstebeginselen van nderelandsburgelijkrecht is neergelegd in de bapeling, dat de verhaalsrect an den schuldeiserzichuitstreken over alleroerendeenonroerendegoederen van den schuldenaar, zowel die hijheeftals die hijzalkrijgen," 30 which means one of the most paramount principles of national civil law is the fact that creditors can handle all properties that are both movable and immovable, both owned or intended to receive.

The principle of creditorium parity (equality of creditor's position) determines equal rights to all of a debtor's property. ${ }^{31}$ If the debtor can not pay his debt, the debtor's assets are targeted by creditors. ${ }^{32}$ The assets are subject to all a debtors' assets whether movable or immovable property. Assets owned by the debtor and goods of which the debtor will have in the future are also bound to the settlement of debtor's obligations. ${ }^{33}$

Creditorium parity protects against the unjust situation when the debtor owns property while the debtor's debt to his creditors is not yet paid. Law provides a legal guarantee as the debtor's assets by law are collateral for his debts even though the debtor's assets are not directly related to those debts. The principle of the creditorium parity is also regulated in Article 1131 Burgerlijk WetboekvoorIndonesie (BW), saying that, "All the materials of the debtors, both movable and immovable, both owned or they will receive, will become a liability for a personal guarantee."

The setting of the minimum authorized capital in Article 25 Act Number 1 of 1995 is Rp20,000,000,- (twenty million rupiah). ${ }^{34}$ The amount is quite large if we adjust with inflation with a 1995 US dollar exchange rate of Rp2,217 (two thousand two hundred seventeen rupiah) per US Dollar. Nonetheless the the amount was appropriate if the purpose of Law Number 1 of 1995 was to ensure that the LLC will be a sustainable company and willing to provide guarantees to the third parties. The large amount is at least a minimum value of the real embodiment assets from an LLC which can be used as collateral for the creditors if the LLC is bankrupt.

The fact that the authorized capital amount regulated in Law Number 1 of 1995 was Rp20,000,000,- (twenty million rupiah) means that there is a minimum guarantee of Rp20,000,000,- (twenty million rupiah) if a third party/creditor engages in legal relations such as debts with the LLC. Thus, it can be said that the minimum amount is a manifestation of the principle of creditorium parity, or guarantee.

30 Vollmari, De Faillessementswet, (Haarlem: TjenkWillink \&e Zoon N.V., 1948) at l.

31 Hadi Shubhan, Hukum Kepailitan: Prinsip, Norma, dan Praktik di Peradilan, (Jakarta: Prenadamedia Group, 2015) at 27.

32 Annisa Amalia Rachmah et al., 'Analisis Yuridis Kedudukan Penjamin Perorangan (Personal Guarantee) Pada Kepailitan Perseroan Terbatas', 5 Nomor 4 Tahun 2016 Diponegoro Law Journal at 5.

33 Hadi Shubhan, supra note 31 at 28 in Kartini Muljadi, Kepailitan dan Penyelesaian Utang Piutang, (Bandung: Alumni,2001) at 168.

34 Article 25 Law No. 1 of 1995 on Limited Liability Company. 
In the process of being implemented, Law Number 1 of 1995 became incompatible with the increasingly rapid economic and business development, both nationally and internationally. Through the Company Law of 2007, the Government increased the amount of authorized capital to at least Rp 50,000,000,- (fifty million rupiah). ${ }^{35}$. This increase was not uncalled for because 12 years of rapid development resulted in the rupiah infalting.

Het Recht Hink Achter De Feiten Aan once claimed that the law always lags behind the event. ${ }^{36}$ This situation is a case in point. The present minimum capital may have been considered sufficient, but in the next five years it may become inadequate. Therefore, Company Law Article 32 paragraph (3) of 2007 provides the possibility of changes in the amount of authorized capital which diverges from the amount of authorized capital regulated in Article 32 paragraph (1) of the Company Law in 2007 Therefore, the law already accounts for change means and a complicated process and legislative interference is not necessary to change the minimum amount.

\section{THIRD PARTIES' LEGAL PROTECTION OVER AUTHORIZED CAPITAL IN GOVERNMENT REGULATION NUMBER 29/2016}

On March 21, 2016, the Government issued Government Regulation Number 7 of 2016. In Article 1 Government Regulation Number 7 of 2016, there was a change in the authorized capital which was originally determined to be at least Rp50,000,000,- (fifty million rupiah) to instead be submitted to the agreement of the founders of LLC where the founding party of LLC has net assets in accordance tothe criteria of the MSMEs. On July 14, 2016, the Government issued a new policy regarding changes for the authorized capital amount. The policy was included in Government Regulation Number 29 of 2016 and implied a change that the authorized capital amount is to alone be submitted to the agreement of the founders of LLC. LLC here is referred in Government Regulation Number 29 of 2016 as both an LLC that meets the criteria of an MSME and large LLC. ${ }^{37}$ Therefore, the process of establishing an LLC no longer requires a minimum nominal amount.

Given the reasoning in formulating Government Regulation Number 29 of 2016 which can be found in the weighing section $^{38}$, the policy aim is to provide businessesgreater ease in establishing ann LLC business entity. Hence, the Government

35 Article 32 Law No. 40 of 2007 on Limited Liability Company.

36 Sudikno Merto kusumo, Beberapa Azas PembuktianPerdata Dan Penerapannya Dalam Praktek, (Yogyakarta: Liberty, 1980) at 3.

37 Large Business is a productive economic enterprise carried out by a business entity with a greater amount of net worth or annual sales proceeds than a Medium Business, which includes national or private-owned businesses, joint ventures, and foreign businesses in Indonesia, which means: a) has a net worth of more than Rpl0,000,000,000.- (ten billion rupiah) not including land and building of the business; or b) has annual sales of Rp50,000,000,000.- (fifty billion rupiah). See Article 1 No. 4 jo. 6 paragraph (3) Law No. 20 of 2008 concerning MSMEs.

38 Consideration in a law provides a brief description of the underlying backgrounds and the reason for the enactment of the legislation. Maria Farida Indrati in Maria Farida Indrati Soeprapto, Ilmu Perundang-undangan Proses dan Teknik Pembentukannya, (Yogyakarta: Kanisius, 2007) at 108. 
senses the urge to provide flexibility to determine the amount of authorized capital in establishing LLC. The issuance of regulations to facilitate this effort in line with the Government's goal to increase the EODB rating in Indonesia to be the 40th in the world, ${ }^{39}$ where one of the indicators in EODB is the starting a business.

Referring to the 2015 EODB ranking, before the enactment of Government Regulation Number 29 of 2016, Indonesia is in the 109th position which is still far behind if compared to Malaysia (ranked 18th), Thailand (ranked 48th), and Vietnam (ranked 90th). ${ }^{40}$ EODB uses 10 (ten) indicators: 1) Ease of starting a business; 2) Dealing with construction permits; 3) Electrical Connection; 4) Property Registration; 5) Credit Access; 6) Protection of Minority Investors; 7) Tax Payment; 8) Cross Country Trade; 9) Contract Enforcement; and 10) Resolving Insolvency (Settlement of Bankruptcy Cases). Within the ten indicators, Indonesia does not receive a low score in starting of business. Thus we can speculate that the Government Regulations Number 29 of 2016 was not entirely in response to the EODB score but rather a socially felt frustration.

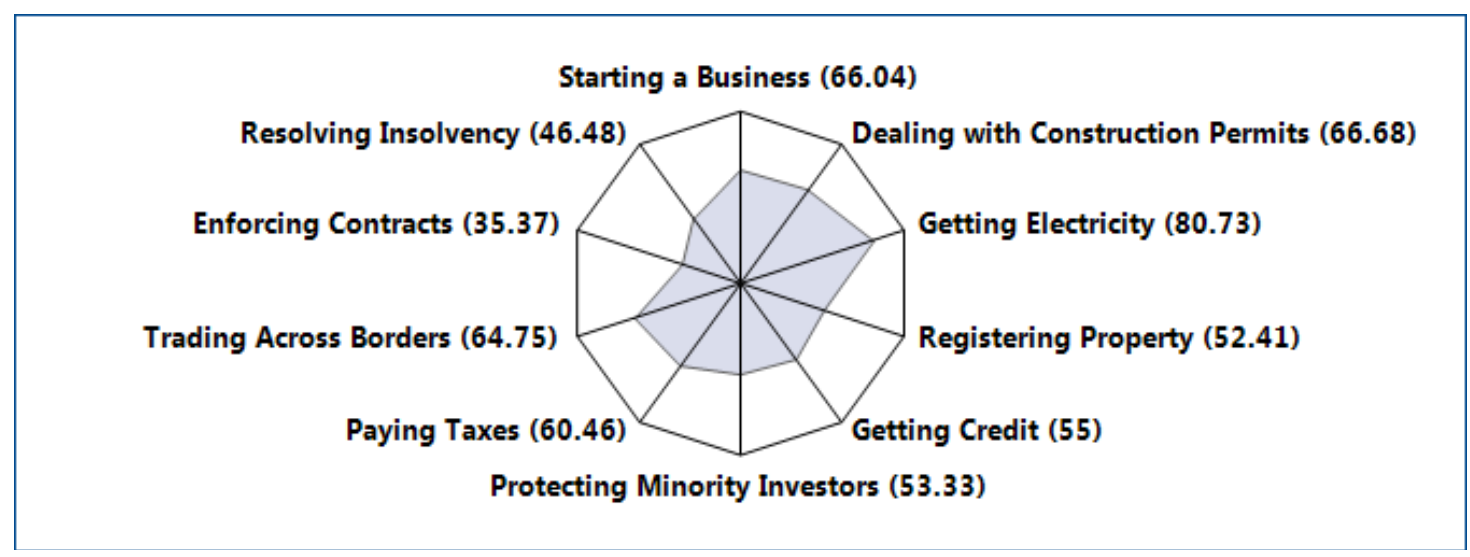

Figure 1.1. EODB Indonesia Indicator Score Table

Source: World Bank Group, Doing Business in 2016 Measuring Regulatory Quantity and Efficiency: Economy Profile 2016 Indonesia, 2016 at 9.

In addition to the starting a business indicator, there are other relevant indicators related to third party protection, such as the criteria for protecting minority investors and resolving insolvency (settlement of bankruptcy cases). The nominal value of the authorized capital has a role in providing protection to minority investors by becoming collateral that is, at least, equal with the minimum authorized capital set by the Government.

The existing minimum amount will also affect the settlement of bankruptcy cases because one of the indicators used to provide an assessment of the settlement of

39 Disfiyant Glienmourinsie, "Jokowi Targetkan Kemudahan Usaha di Indonesia 40 Besar Dunia", (2017), online: < https://ekbis.sindonews.com/read/1203704/33/jokowi-targetkan-kemudahan-usahadi-indonesia-40-besar-dunia-1494304074, >.

40 Business Law, BINUS University. Online: http://business-law.binus.ac.id/2018/04/30/kemudahanberusaha-ease-of-doing-business-terkait-penyelesaian-kepailitan/ 
bankruptcy cases is related to "recovery rate for secured creditor. ${ }^{41}$ The amount of the minimum authorized capital will actually ensure credibility to the creditors, confirmed bythe Chairman of the Law Department in Universitas Sebelas Maret (UNS), Adi Sulistiyono, who said that the Government had neglected the aspect of protection for third parties over changes in the capital requirements of a company. ${ }^{42}$ Initially, the minimum authorized capital was Rp 50,000,000,- (fifty million rupiah) so that third parties would be protected when cooperating or partnering with an LLC. ${ }^{43}$

Thus, the elimination of the minimum amount removes any legal protection for third parties.

\section{Posisi Indonesia pada 10 Indikator}

\begin{tabular}{|c|c|c|c|}
\hline Indikator & $\begin{array}{l}\text { DB } \\
2017\end{array}$ & $\begin{array}{l}\text { DB } \\
2016\end{array}$ & Perubahan \\
\hline & 91 & 106 & 仓 15 \\
\hline Memulai Usaha & 151 & 167 & نे 16 \\
\hline $\begin{array}{l}\text { Perizinan Terkait Mendirikan } \\
\text { Bangunan }\end{array}$ & 116 & 113 & 7 \\
\hline Penyambungan Listrik & 49 & 61 & 仓 12 \\
\hline Pendaftaran Properti & 118 & 123 & 仓 \\
\hline Akses Perkreditan & 62 & 70 & 仓 \\
\hline $\begin{array}{l}\text { Perlindungan Terhadap Investor } \\
\text { Minoritas }\end{array}$ & 70 & 69 & $\nabla$ \\
\hline Pembayaran Pajak & 104 & 115 & 仓 11 \\
\hline Perdagangan Lintas Negara & 108 & 113 & 仓 \\
\hline Penegakan Kontrak & 166 & 171 & ن \\
\hline Penyelesaian Perkara Kepailitan & 76 & 74 & 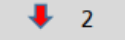 \\
\hline
\end{tabular}

\begin{tabular}{|lc} 
Peringkat EoDB 2017 & $\begin{array}{c}\text { PNB per } \\
\text { Kapita } \\
\text { (USD) }\end{array}$ \\
\hline SINGAPURA (2) & 52.090 \\
\hline A. THSTRALIA (15) & 60.070 \\
\hline TIONGKOK (78) & 7.820 \\
\hline INDONESIA (91) & 3.440 \\
\hline INILIPINA (99) & 3.540 \\
\hline
\end{tabular}

Figure 1.2. Indonesia's Position on EODB's ten indicators

Source: www.bkpm.go.id

In the effort to achieve the higher starting a business to raise the rating of EODB Indonesia, the submission of the amount of authorized capital to the founders of LLC instead of a capital minimum, is intended as an effort from the Government to respect the principle of freedom of and provide more possibilites for the public to enter into a Limited Liability Company based on provisions in civil law. ${ }^{44}$ From a further examination, the nature of the establishment of LLC is based upon an agreement which indicates that the agreement is an absolute necessity in the establishment of LLC. The

41 Doing Business, Resolving Insolvency, online: 〈http:/www.doingbusiness.org/en/methodology/ resolving-insolvency>.

42 Hukumonline. "PP 29/2016 'Simpangi’ Besaran Modal Dasar Pendirian Perseroan Terbatas?”, (2016), online: < https:/www.hukumonline.com/berita/baca/lt57a205bfb73c9/pp-29-2016-simpangi-besaranmodal-dasar-pendirian-perseroan-terbatas/>.

43 Ibid.

44 General Overview on Law Number 29 of 2016 regarding Amendments on Authorized Capital of a Limited Liability Company. 
agreed pact in the establishment of LLC established fundamental policies and procedures such as determining the initial amount of the authorized capital.

Contrary to what some may think, a required, initial amount of authorized capital does not diminish the principle of freedom of contract. This assumption still seems to perceive freedom of contract as the primary principle in an agreement where parties are genuinely autonomous and freed to form any agreement. However, along with the progression of time, the principle's meaning has been gradually reduced as stated by some scholars. Subekti ${ }^{45}$ said that contract law faced the increasing restrictions on the freedom of contract after World War II. Unbalanced bargaining positions made freedom of contract limited substantial contractual freedom.. ${ }^{46}$ According to Pitlo, the restriction on freedom of contract is one of breakthroughs in law that was originally centered on private interests to become a public interest. ${ }^{47}$ Pitlo described that if it used to be uitholing van eigendom, there is now a uitholling van contractvriheid. ${ }^{48}$

In Indonesia, the principle of freedom of contract is reflected in the Article 1338 paragraph (1) BW, which stated: "All agreements made legally in accordance with the law apply as laws for those who made them." According to Subekti ${ }^{49}$, the way to understand the principle of freedom of contract is to emphasize the word "all" before the word "agreement." The article is often misinterpreted to suggest that every agreement will legally bind signees of a contract. But freedom of contract as concluded from the provisions of Article 1338 paragraph (1) BW does not exist in isolation. The principle is a part of a bigger scheme where it is pertinent and intertwined with other related provisions. To strengthen the whole system, the implementation of the Article 1338 paragraph (1) BW must be linked to other articles, which are: ${ }^{50}$

a) Article $1320 \mathrm{BW}$, elaborates the legal terms of the agreement (contract);

b) Article $1335 \mathrm{BW}$, prohibits the making of contracts without causa, or is made based on a false or prohibited cause, with the consequence of losing power;

c) Article $1337 \mathrm{BW}$, states that a reason is prohibited if prohibited by law or if it is contrary to decency or public order;

d) Article 1338 paragraph (3) BW, stipulates that the contract must be carried out in a good faith;

e) Article 1339 BW, states that the binding of the agreement must refer to the nature, propriety, custom, and law; and

f) Article $1347 \mathrm{BW}$, regulates the customary stipulation (bestandiggebruiklijkbeding).

Bearing in mind that article 1338 paragraph (1) BW is systematically formulated by other articles in a framework of the legal system (vide Article 1320, 1335, 1337, 1338 (3) and $1339 \mathrm{BW})$, the implementation of the principle of freedom of contract has been

\footnotetext{
45 Mariam Darus Badrulzaman, Perjanjian Kredit Bank, (Bandung: Citra Aditya Bakti,1991) at 44.

46 Ibid at 111 .

47 Ibid.

48 Agus Yudha Hermoko, Hukum Perjanjian: Asas Proporsionalitas dalam Kontrak Komersial, (Jakarta, Prenadamedia Group, 2014) at 113.

49 Subekti, Aneka Perjanjian, Cet. Keenam, (Bandung: Alumni, 1995) at 4-5.

50 Agus Yudha Hermoko, supra note at 118.
} 
framed by other legal signs. Mariam Darus Badrulzaman ${ }^{51}$ added that the Government intervention was a shift of Civil Law into a correctional process (vermaatschappelijking) for the public interest as a result from the alteration of UUD 1945's detachment to liberal legal conceptions toward a "Pancasilais" conception of law. Practically, Civil Law, especially Contract Law, seeks new forms to fulfill people demands and does that through the allowance of government intervention. Materials relating to the public interest will thus provide legal protectionThese materials tend to multiply the dwingendrechtin order to protect the weak.

The regulation regarding the initial authorized capital should also be a form of Government intervention in the contract. The capital amount would provide legal protection to third partie.. In providing legal protection, the legal subject is not only the parties who set up LLC but also third parties because the contract is related further to those who will later establish legal relations with the LLC. Satjipto Rahardjo states that the presence of law within society is to integrate and coordinate interests that could collide with each other. ${ }^{52}$ Coordinating these interests is done by limiting and providing protection against them. ${ }^{53}$ In line with this, the task of providing legal protection against conflicts of interest of the parties is the responsibility of the Government

\section{THE FORMULATION OF THIRD PARTIES' LEGAL PROTECTION RELATED TO THE DETERMINATION OF AUTHORIZED CAPITAL AMOUNT}

As stated by Philipus M. Hadjon, there are two kinds of legal protection; preventive and repressive legal protection. ${ }^{54}$ Preventive legal protection is a protection provided by the Government to prevent the occurrence of violations. This protection aims to hinder a violation and offer limitations in performing obligations. Repressive legal protection is the final protection in the form of sanctions such as fines, imprisonment, and additional penalties given when a dispute has occurred or an action has been committed. These two forms of legal protection cannot be separated from one another and always go hand in hand. The preventive legal protection, in this context, is proposed by the author as a form of determining the initial authorized capital amount and a formation of different types of new legal entities from LLC. At the same time, the kind of repressive legal protection recommended by the author is administrative sanctions against business actors who deviate from the provisions stipulated by the legislation.

$51 \quad$ Ibid.

52 Satjipto Rahardjo, Ilmu Hukum, (Bandung:Citra Aditya Bakti, 2000) at 53.

53 Ibid, at 54.

54 Barzah Latupono, "Perlindungan Hukum dan Has Asasi Manusia terhadap Pekerja Kontrak (Outsourcing) di Kota Ambon" (2011) 17:3 Jurnal Sasi, at 67. 


\section{A. Preventive Legal Protection}

The presented solution is to re-establish the minimum amount of the initial authorized capital needed to establish an LLC. The amount should not small because it will not provide enough protection to third parties' On the other hand, the amount should not be too high to the extent that it would inhibit the establishment of an LLC. The beginning of the authorized capital amount stipulated in Article 25 of Act Number 1 of 1995 is Rp 20,000,000,- (twenty million rupiah) and in Article 32 of the Company Law the amount is set to be Rp50,000,000,- (fifty millions rupiah).

The authorized capital amount recommended by the author is $\mathrm{Rp} 100,000,000$,(one hundred million rupiah). It is given due the consideration as the law has been issued for almost 11 years. The exchange rate of the rupiah used in the year of 20072008, which was between Rp9000-Rp10.000 ${ }^{55}$, has now be in the range of Rp 14,000. ${ }^{56}$ Inflation that continues to increase should be perceived to be the ratio legis to determine the amount of Rp 100,000,000,- (one hundred million rupiah) as the minimum. The law should also allow for flexibility and opportunities for change because of potential, dynamic economic developmentsThe stipulation is critical so that the determination of the authorized capital amount can be substantially adjusted in accordance to the development of the Indonesian economy. Nevertheless, the authorized capital amount could also be reduced consecutively with the improvement of the Indonesian economy to fulfill the proportional ${ }^{57}$ principle.

In order to increase the EODB rating cumulatively, the Government can accommodate a new legal entity.. This legal entity will have the same objective with LLC as a separate legal entity but will not be allowed to sell its shares openly in the capital market and there will be no stipulation of minimum authorized capital amount by the Government. Looking at current Indonesia's status quo, the only profit oriented legal entity is an LLC. However, the other profit-oriented business entities such as CVs and Firms have no separation of assets between the entities' and

The concept of the new business entity should be similar the Netherlands' concept of beslotenvennootschap (BV). ${ }^{58}$ The ratio legis behind the unspecified minimum capital for a private enterprise is that the shareholders mostly have a close relationship (family, friend, or close relative) to avoid ownership shifts as a result of being sold. It can be seen that these shares only come from groups of intimate and familiar people.. ${ }^{59}$ This is different from the go-public company where it is necessary to provide protection for third parties who are an outsider and is truly a profit-oriented entity. The

\footnotetext{
55 Angga Aliya. “PP 29/2016 'Perjalanan Dolar AS Dari Rp 2.000 Kini Rp 13.300?”, (2015), online: < https:/finance.detik.com/bursa-dan-valas/d-2943614/perjalanan-dolar-as-dari-rp-2000-kini-rp13300>.

56 Dea Chadiza Syafina, “Apakah Dolar akan Balik Lagi ke Rpl5.000 pada 2019?”, (2019), online: 〈https://irto.id/apakah-dolar-akan-balik-lagi-ke-rpl5000-pada-2019-dcTE〉

57 The word "proportional" is chosen because it shows that the determination of the authorized capital nominal must not be too small or too big.

58 Lars van Vliet, supra note 29 at 272.

59 Ibid at 275.
} 
establishment of this new legal entity can improve business conduct at one point but also can fulfill the legal protection for third parties.

\section{B. Repressive Legal Protection}

The differentiation between the LLC and the new proposed legal entity is intended to facilitate the implementation of a minimum authorized capital amount regulation. The Government should also control and impose sanctions if a specific LLC deludes the minimum amount. The sanctions had not been regulated even when the minimum capital was still regulated in the Company Law. In line with the proposed solution, the author argues that sanctions against the perpetrators are needed.

\section{CONCLUSION}

The determination of the minimum amount of authorized capital in establishing an LLC is a form of legal protection for third parties and, specifically, a guarantee for those who cooperate with the LLC. Government Regulation Number 29 of 2016 currently allowsthe founders to establish an LLC with an internal agreement about the amount of authorized capital. The policy, which was originally oriented to boost the indicator of starting business in EODB, seems to neglect the protection of third parties as it can diminishes efforts towards protecting minority investors and resolving insolvency. Consequently, without a minimum, there is no legal certainty for both the founders and the third parties.Today's economic situation has changed since the enactment of the company law (Undang-Undang Perseroan Terbatas) 11 years ago and thus Rpl00.000.000,(one hundred million rupiah) minimum amount of the initial authorized capital to establish an LLC would protect LLC third party investors. In terms of repressive legal protection, the government can issue administrative sanctions to an LLC that violates the minimum nominal.

\section{REFERENCES}

Agus Yudha Hermoko, Hukum Perjanjian: Asas Proporsionalitas dalam Kontrak Komersial, (Jakarta, Prenadamedia Group, 2014).

Azizah, Hukum Perseroan Terbatas, (Intimedia: Malang, 2015)

GatotSupramono, Kedudukan Perusahaan Sebagai Subjek dalam Gugatan Perdata di Pengadilan, (Jakarta: Rineka Cipta, 2007).

Gatot Supramono, Transaksi Bisnis Saham e Penyelesaian Sengketa Melalui Pengadilan, (Jakarta: Pranamedia Group, 2014).

Hadi Shubhan, Hukum Kepailitan: Prinsip, Norma, dan Praktik di Peradilan, (Jakarta: Prenadamedia Group, 2015).

Kartini Muljadi, Kepailitan dan Penyelesaian Utang Piutang, (Bandung: Alumni, 2001).

Man S. Sastrawidjaja dan Rai Mantili, Perseroan Terbatas Menurut Tiga Undang-undang Jilid 1, (Bandung: Alumni, 2008). 
Maria Farida Indrati Soeprapto, Ilmu Perundang-undangan Proses dan Teknik Pembentukannya, (Yogyakarta: Kanisius, 2007).

Mariam Darus Badrulzaman, Perjanjian Kredit Bank, (Bandung: Citra Aditya Bakti, 1991),

Satjipto Rahardjo, Ilmu Hukum, (Bandung: Citra Aditya Bakti, 2000)

Subekti, Aneka Perjanjian, Cet. Keenam, (Bandung: Alumni, 1995).

Vollmari, De Faillessementswet, (Haarlem: TjenkWillink\& Zoon N.V., 1948).

Yahya Harahap, Hukum Perseroan Terbatas, (Jakarta: Sinar Grafika, 2016).

Sudikno Mertokusumo, Beberapa Azas Pembuktian Perdata Dan Penerapannya Dalam Praktek, (Yogyakarta: Liberty, 1980).

World Bank, Doing Business in 2016 Measuring Regulatory Quantity and Efficiency: Economy Profile 2016 Indonesia, (Washington: World Bank Group, 2016).

Agus Riyanto, “Mengapa Harus Memilih Perseroan Terbatas?” (2014), 1:1 Jurnal Widya Yustisia.

Annisa Amalia Rachmah et al., 'Analisis Yuridis Kedudukan Penjamin Perorangan

(Personal Guarantee) Pada Kepailitan Perseroan Terbatas', (2016) 5:4 Diponegoro Law Journal.

Bahmid, "Perubahan Persekutuan Perdata Menjadi Badan Hukum Perseroan Terbatas" (2018) 2:4 Jurnal Pionir LPPM Universitas Asahan.

Barzah Latupono, "Perlindungan Hukum dan Has Asasi Manusia terhadap Pekerja Kontrak (Outsourcing) di Kota Ambon” (2011) 17:3 Jurnal Sasi.

Gledisia Deyaperdana, "Pelaksanaan Tanggung Jawab Sosial Perusahaan PT Indosat Tbk

(Studi Pada Kantor Perwakilan Kotabumi)" (2010) Thesis Faculty of Law Universitas Lampung.

Joshua Agustha, "Inkonsistensi Pengaturan Modal Dasar Dalam Pendirian Perseroan Terbatas Terhadap Tujuan Kepastian Hukum" (2017) Thesis Faculty of Law Universitas Atmajaya Yogyakarta.

Lars van Vliet, "The Netherlands - New Developments in Dutch Company Law: The "Flexible" Close Corporation" (2014) 7:1 J. Civ. L. Stud.

Nabila Jofita Kumalasari, "Perlindungan Hukum Pihak Ketiga Terhadap Modal Perseroan Terbatas Berdasarkan Peraturan Pemerintah Nomor 29 Tahun 2016 Tentang Perubahan Modal Dasar Perseroan Terbatas" (2018) Thesis Faculty of Law Universitas Airlangga.

Yohana Feryna, "Makna Kesepakatan Para Pihak Terhadap Perubahan Modal Dasar Perseroan Terbatas" (2016) 7: 2 Jurnal Cakrawala Hukum.

Yoahana, "Tanggung Jawab Hukum Atas Bentuk Usaha Badan Hukum Dan Bentuk Usaha Non Badan Hukum" (2015) 8: 1 Jurnal Mecatoria.

BKPM, "Perbaikan Pelaksanaan Kemudahan Berusaha Ease of Doing Business di Indonesia”, 2017, www.bkpm.go.id/images/uploads/whyinvest_file/Greenlab_ BKPM_Web_2017_Materi_Download-EoDB_Ind_20171110.pdf. 
Disfiyant Glienmourinsie, "Jokowi Targetkan Kemudahan Usaha di Indonesia 40 Besar Dunia”, 2017, https:/ekbis.sindonews.com/read/1203704/33/jokowi-targetkankemudahan-usaha-di-indonesia-40-besar-dunia-1494304074.

Elisa Valenta Sari, "Pemerintah akan Hapus Syarat Modal Dasar Pembentukan PT", 3 March 2016, https:/www.cnnindonesia.com/ekonomi/20160303183125-92115198/pemerintah-akan-hapus-syarat-modal-dasar-pembentukan-pt.

Hukumonline.com, "Jenis Badan Usaha dan Karakteristiknya", 20 March 2012 https:/www.hukumonline.com/klinik/detail/lt4f51947253585/jenis-jenis-badanusaha-dan-karakteristiknya.

Hukumonline.com, "Perbedaan Modal Dasar, Modal Ditempatkan, dan Modal Disetor PT”, 16 June 2010 https:/www.hukumonline.com/klinik/detail/lt4cd0bd0284a7l/ perbedaan-modal-dasar--modal-ditempatkan--dan-modal-disetor-pt.

Hukumonline.com, "PP 29/2016 'Simpangi' Besaran Modal Dasar Pendirian Perseroan Terbatas?", 2016, https://www.hukumonline.com/berita/baca/lt57a205bfb73c9/ pp-29-2016-simpangi-besaran-modal-dasar-pendirian-perseroan-terbatas/.

Legalakses, "Modal Perseroan Terbatas", 2014, http://www.legalakses.com/modalperseroan-terbatas/.

Mega Herdiana, "Pendirian Perseroan Terbatas", 17 January 2019, http://www.legal4ukm.com/pendirian-perseroan-terbatas-pt/.

R24, "Socrates dan Definisi Terorisme", 2018, https://pinterpolitik.com/socrates-dandefinisi-terorisme/.

Siti Yuniarti, "Perubahan Modal Dasar Perseroan Terbatas" 2016, http://businesslaw.binus.ac.id/2016/04/29/perubahan-modal-dasar-perseroan-terbatas/.

The World Bank Group, "Rankings \& Ease of Doing Business Score", 2019, http://www.doingbusiness.org/en/rankings.

The World Bank Group, "Resolving Insolvency Methodology", 2019, http://www.doingbusiness.org/en/methodology/resolving-insolvency

Binus University Faculty of Humanities, "Kemudahan Berusaha (Ease of Doing Business) TerkaitPenyelesaianSengketaKepailitan”, 2018, http://businesslaw.binus.ac.id/2018/04/30/kemudahan-berusaha-ease-of-doing-business-terkaitpenyelesaian-kepailitan.

Dea Chadiza Syafina, “Apakah Dolar akan Balik Lagi ke Rpl5.000 pada 2019?”, 2019, https://tirto.id/apakah-dolar-akan-balik-lagi-ke-rpl5000-pada-2019-dcTE. 